\title{
NEUROFUNCTIONAL AREAS RELATED TO FOOD APPETENCY IN ANOREXIA NERVOSA
}

\section{Áreas neurofuncionales relacionadas con la apetencia a los alimentos en la Anorexia Nervosa}

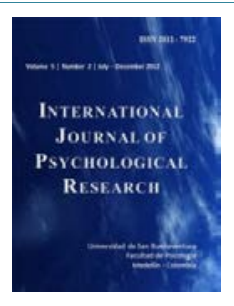

\author{
Juán José Cervantes-Navarrete ${ }^{\mathrm{G} \text { 国, a }}$, Sarael Alcauter-Solórzano b, Carlos Miguel-Bueno ${ }^{\text {, }}$, Jorge Julio Gonzalez- \\ Olvera ${ }^{\mathrm{a}}$, Roger Carrillo-Mezo ${ }^{\mathrm{d}}$, Maria de Lourdes Martínez-Gudiño b, Alejandro de Jesús Caballero-Romo . \\ a Investigador en Ciencias Médicas, Subdirección de Investigaciones Clínicas del Instituto Nacional de Psiquiatría, Ciudad de México \\ b Departamento de Imágenes Cerebrales del Instituto Nacional de Psiquiatría, Ciudad de México \\ C Centro Michoacano de Salud Mental, Morelia Michoacán, México \\ d Departamento de Neuroradiología del Instituto Nacional de Neurología y Neurocirugía, Ciudad de México \\ e Coordinador de la Clínica de Trastornos de la Conducta Alimentaria del Instituto Nacional de Psiquiatría, Ciudad de México
}

\begin{abstract}
In Anorexia Nervosa the observable phenomenon is the suppression of appetite. Little is known about the biological and psychological (top-down) bases that maintain this pathological state. However, Anorexia Nervosa is a biological, psychological and social model where the main behavioral characteristic is the inhibition of eating behavior; not by bottom-up but top-down regulation. Objective: To explore the areas of the brain associated with food appetency through functional magnetic resonance in women with anorexia nervosa. Methods: The subjects include 5 female with Restrictive type of Anorexia Nervosa and five controls female with similar in age and low weigh. The subjects were within the MRI scanner and while took fMRI they saw food images that would generate appetite. The subjects were in fasting state and mentally prepare by instruction "imagine you are eating the food presented in the following images". Results: Compared differences in the activation between subjects four regions were found significant: the anterior cingulate, left front medial region and the left and right midbrain. Conclusions: The patients with Anorexia Nervosa present different activated cerebral areas to those of the controls during the visual exposition to food in hungry state and with evoke cognitions associated with eat food; those regions may be implicated in reward and self-control.
\end{abstract}

\section{RESUMEN}

En la Anorexia Nervosa se observa un fenómeno que es la supresión del apetito. Poco se conoce sobre los factores biológicos y psicológicos (top-down) que mantienen este estado patológico. De cualquier modo la Anorexia Nervosa es un modelo biológico, psicológico y social de donde la principal característica conductual es la inhibición de la conducta alimentaria. Objetivo: Explorar las áreas cerebrales asociadas a la apetencia de los alimentos mediante la Resonancia Magnética Funcional en mujeres con Anorexia Nervosa. Métodos: Los sujetos fueron cinco mujeres con Anorexia Nervosa Restrictiva y cinco mujeres controles de similar edad y de bajo peso. Los sujetos fueron introducidos al resonador magnético mientras observan imágenes evocadoras de apetencia, en estado de ayuno y bajo la instrucción de imaginar que estaban comiendo lo que se les presentaba. Resultados: Al comparar las diferencias en las áreas de activación entre los sujetos cuatro regiones difirieron significativamente el cingulo anterior, la región frontal medial izquierda y derecha e izquierda del mesencéfalo Conclusiones: Las pacientes con anorexia nervosa presentaron áreas de actividad cerebral diferentes que los controles durante la exposición visual de comida en estado de hambre y con la evocación de pensamientos con el comer; estas regiones pudiesen estar implicadas con el reforzamiento y el auto-control.
Key Words:

Anorexia Nervosa, food appetency, appetite, neuroimaging

\section{Palabras Clave:}

Anorexia Nervosa, Apetencia, Apetito, Neuroimagen

Juán José Cervantes-Navarrete, Investigador en Ciencias Médicas, Subdirección de Investigaciones Clínicas del Instituto Nacional de Psiquiatría, Ciudad de México. E-mail cervantes@imp.edu.mx

\begin{tabular}{l|l|l||} 
I J P R & ISSN impresa (printed) 2011-2084 ISSN electrónica (electronic) 2011-2079
\end{tabular} 


\section{INTRODUCTION}

Food appetency is a physiologically motivational state oriented to the intake of food and a reaction to the depletion of nutrients. During evolution this has allowed organisms to acquire the nutrients of their surroundings for their adequate function and development (Morrison \& Berthoud, 2007). The physiology involved in food appetency, just as in other functions, has its regulatory center in the brain (Kishi \& Elmquist, 2005). This system can be divided in two parts: homeostatic and nonhomeostatic pathways (Berthoud, 2006). The homeostatic pathway is in charge of maintaining the balance between the intake and the metabolism; whereas, the non-homeostatic pathways is linked to the eating behavior, mediated by mental representations as pleasing effects of food; itself divided in two components: the anticipatory and the consummatory (Barbano \& Cador, 2005). The anticipatory component functions mostly with dopamine, is responsible of the food searching states or those with an intense desire to eat, and it involve the mesencephalic dopaminergic centers (Davis et al., 2009); while the consuming component does so with endocannabinoids and opiates, and it is responsible of pleasure when degustation (Kirkham, 2009).

In some mental disorders food appetency becomes an intense motivation, as well as in some motivationally addictive states. Such is the case of some psychopathologies considered in the spectrum of eating disorders such as Binge Eating and Bulimia Nervosa, where the desire to ingest food is increased and hard to control; this symptom is called binge and it is pathognomonic in regard to the appetency alteration in those entities. (Allison \& Timmerman, 2007).

Appetency is an important phenomenon in Anorexia Nervosa; in this case the observable behavior is the alimentary conduct suppression because of the inhibited intake. However, it is not possible to determine the magnitude of the auto-control influence, that is to say, patients feel hunger that is intentionally controlled (Top-Down Mechanism) (Ceaser, 1979; Fernstrom \& Choi, 2008) or the inhibition of intake is produced by the appetite decrease (Wagner et al., 2008) because of the hunger reduction or the urgency to eat (bottom-up mechanism). There are several difficulties to examine appetency in patients with anorexia, including the fact that they are inexact and reluctant to expressing their corporal feelings and food likes (Hetherington \& Rolls, 1991), which is difficult because appetency is expressed in an independent way and it is experienced as a corporal feeling (Northoff, 2012). That is why, it is important to point out that discrepancies are possible among the experience (Phenomenological, subjective level, first person), what patient expresses (Intersubjective level, second person) and what the researcher reports as an observable phenomenon (Third person) (Vallor, 2008).

Little is known about the biological bases that maintain the pathological state denominated Anorexia Nervosa. However, multiple mechanisms have been involved that include neurotransmitters and hormones related to eating behavior, besides the cortical areas that maintain a self-starvation behavior (Kaye, Fudge, \& Paulus, 2009). The self-starvation behavior seen in anorexia nervosa has also been related to the mesolimbic dopamine reward system (Fladung et al., 2010; Scheurink, Boersma, Nergårdh, \& Södersten, 2010; Keating, Tilbrook, Rossell, Enticott, \& Fitzgerald, 2012).

Anorexia nervosa is a psychiatric disorder that is diagnosed once the following criteria DS-IV-TR criteria: a lower than $85 \%$ weight, which is equivalent to a body mass index of less than $17.5 \mathrm{~kg} / \mathrm{m}^{2}$; an intense fear of gaining weight; body image distortion and amenorrhea. There are two types of anorexia nervosa: the restrictive and the compulsive purgative type; in this last one the behaviors that are used to maintain a low body weight are basically purges, while in the restrictive type restriction and fasting prevail (American Psychiatric Association, 2000). Only patients of the restrictive type without history of binge-purge periods were included in this study because of their ability to suppress the alimentary behavior, which means to control appetency, by means of fasting and restriction without fits of lack of control in appetency or binges, which happens in purgative compulsive anorexia nervosa.

In anorexia nervosa the observable phenomenon is the suppression of appetite, which gives the disorder its name. This apparent absence of appetite in anorexia nervosa is manifested in the characteristic eating behavior of the disease, which includes: fasting and restriction, with the consequential malnutrition, amenorrhea and other health complications. Paradoxically, it has been reported that these patients may have an intense appetite for food, and it is controversial the implication that autocontrol has in the intake (Gendall, Sullivan, Joyce, \& Bulik, 1997). This discrepancy between the subjective and objective aspect of food appetency in patients with anorexia nervosa inspired the present study. The objective of this study was to explore the areas of the brain associated with food appetency 
through functional magnetic resonance in women with restrictive anorexia nervosa, in a state of fasting and they tried to think of something pleasant with that they are to eating what they see.

\section{MATERIAL AND METHODS}

\subsection{Subjects:}

This study included 5 female patients of the Eating Disorders Clinic of the National Psychiatric Institute, in México City; right handed, who fulfilled the required criteria in order to complete the diagnosis of Restrictive Anorexia Nervosa, evaluated through a diagnostic interview of the Clinic in base of DSM-IVTR criteria(American Psychiatric Association, 2000), between ages 19 to 24 , that accepted to participate in the study. The criteria for exclusion were psychotic conditions or a known neurological condition.

The comparative group was made up of 5 women, right handed, without an eating disorder, or any other psychiatric disorder, evaluated with the same Eating Disorders Clinic protocol, within the same age group, with a body mass of less than 21 and that accepted to participate in the study.

\subsection{Selection of images used to entice food appetency:}

The initial process was to validate the group of food images that would generate appetite in the subjects. A selection criterion was the cultural value of the food, taking into account that only foods that had been ingested previously would generate appetency. For this purpose the images were taken in trying to include a wide range of Mexican popular gastronomic culture, concerning to the central region (A. G. De'Angeli \& De'Angeli, 1993), with high calorie content to generate appetency; some examples are tacos, tamales, quesadillas, sopes, tortas, gorditas, tlacoyos, etc. The images were appetizing for the population of the study; 80 were chosen from the total number of images. A scale of 5 ordinal categories was made to measure how appetizing the food was, it went from not at all appetizing to too appetizing. A group of 50 people graded the 80 images with this scale. 30 images were chosen with the highest marks in appetency and with least variability in grades that would best adapt to this method, where the highest media is taken into account and the least standard deviation.

\subsection{Paradigm of the evocation of food appetency and mental imagery of eat}

Two groups of photographs were formed: 30 neutral images (landscapes) and the 30 images of food that had been previously selected. With these 60 images, 7 blocks were formed; one block of neutral images was alternated with a block of food image and so on. Each block consisted of 10 images and only the first and last block had 5 neutral images, presenting each image for two seconds. During the presentation of the images we gave the instruction: "imagine you are eating the food presented in the following images" (Pylyshyn, 2003; Willems, Toni, Hagoort, \& Casasanto, 2010). Before the study all subjects were in hungry state by means of fasting state more than 16 hours in the morning.

This design of blocks was presented while the images were taken with functional MRI. Once the subjects were within the MRI scanner the food images were showed and we gave the instruction. Images were presented to participants through Avotec's Silent Vision (Avoteclnc, Florida, USA), a specialized MRI compatible hardware.

Images were acquired with a Philips Achieva 3 Tesla MRI scanner (Philips Medical System, Best Eindhoven, Holland), using a 6-channel sense headcoil. High-resolution T1 weighted images were acquired with a 3D Turbo Fast Field Echo pulse sequence in axial plane. Images sensitive to BOLD effect (Blood Oxygen Level Dependent) (Ogawa, Lee, Nayak, \& Glynn, 1990) were acquired with an echo planar gradient echo pulse sequence (TR= $2000 \mathrm{~ms}$, TE= $35 \mathrm{~ms}$ ) in axial plane covering the whole brain in all participants. Final in-plane resolution resulted in $3.6 \times 3.6 \mathrm{~mm} 2$ and slice thickness of $4 \mathrm{~mm}$ without gap between the 30 slices acquired. Functional images were analyzed with FEAT as part of FSL (Smith et al., 2004; Woolrich et al., 2009). Preprocessing of images included slice timing and motion correction, including motion parameters as a confounding variable. A gaussian kernel with FWHM of $6 \mathrm{~mm}$ was used to smooth the images. First level analysis (intrasubject analysis) is based on general linear modeling implemented with FILM (Woolrich et al., 2009), which includes timeseries prewhitening. Results were normalized to standard space using Montreal Neurological Institute's MNI152 Atlas. Second level analysis (group analysis), a fully generalized mixed effects group analysis using Bayesian estimation techniques was applied using FLAME (Beckmann, Jenkinson, \&Smith, 2003). Statistic threshold was set to $p<0.05$, corrected for multiple comparisons. Contrasts were 
designed to show the regions where patients showed more activation than controls.

\section{RESULTS:}

3.1. Evocation paradigm of food appetency presented to the group of patients and the control group:

When the different areas of activation during the task in the patients with Anorexia Nervosa to those of the Comparative Group were compared, with a significance level fixed on $p<0.05$, corrected for multiple comparisons, three regions were found with significant differences in the activation through voxels: the Anterior Cingulate $(Z=4.56, p<0.001)$, the left front medial region $(Z=4.31, p<0.001)$, the left $(Z=4.5, \quad p=0.002)$ and right midbrain $(Z=5.25$, $\mathrm{p}=0.002)$ table 1 and figure 1 .

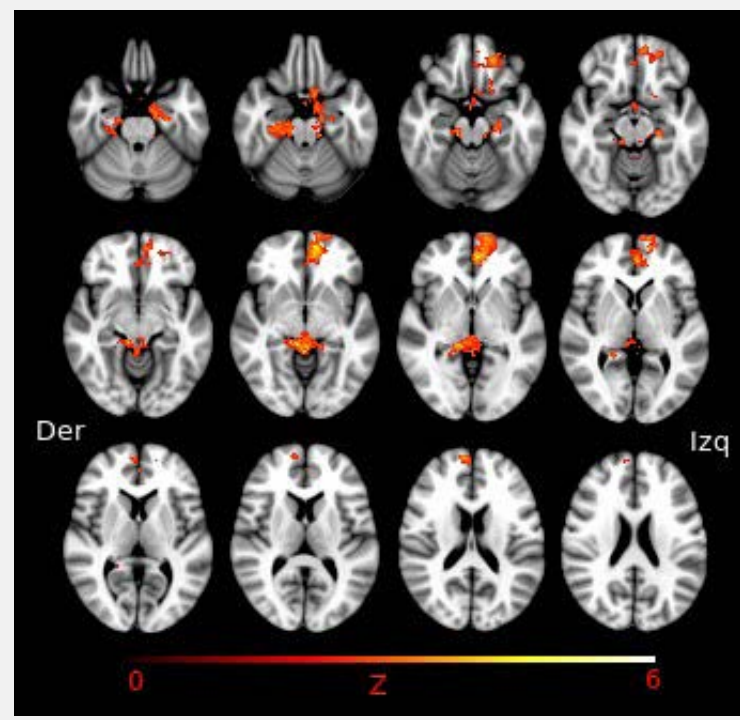

Figure 1.The regions with significantly greater activation in patients with respect to controls are shown in warm colors.

\begin{tabular}{|c|c|c|c|c|}
\hline \multicolumn{5}{|c|}{ TABLE 1 } \\
\hline \multicolumn{2}{|c|}{ Regions with greater activation in patients than in controls } \\
\hline Cerebral region & $\mathbf{Z}$ & \multicolumn{2}{|c|}{ MNI space coordinates (mm) } \\
\cline { 3 - 5 } & $\mathbf{X}$ & $\mathbf{y}$ & $\mathbf{Z}$ \\
\hline Anterior Cingulate & 4.56 & -8 & 48 & -2 \\
\hline $\begin{array}{c}\text { Left frontal medial } \\
\text { area, Brodmann } \\
\text { area 10 }\end{array}$ & 4.31 & -12 & 54 & -6 \\
\hline $\begin{array}{c}\text { Right Midbrain } \\
\text { Left Midbrain }\end{array}$ & 5.25 & 6 & -36 & -6 \\
\hline
\end{tabular}

Cervantes-Navarrete et al IJPR 5(2) 2012 PP. 91 - 97

\section{DISCUSSION:}

Both controls and patients showed different areas of activation, which would imply the intervention of different neurological processes between patients of Anorexia Nervosa and Controls when presented with the same stimulus that generates food appetency and deliberately evoke cognitions associated with eating by instruction.

Including instruction related to mental imagery (Pylyshyn, 2003) allows us to explore subjective situations that are not only the eating experience or the mere exposure to images that stimulate appetency (De Silva, Salem, Matthews, \& Dhillo, 2012; Santel, Baving, Krauel, Münte, \& Rotte, 2006), but also the hypothetic situation of doing an activity that is inhibited in these patients such as the alimentary behavior. (Gatward, 2001). This exploration of the patient's subjective field allows revealing the activated areas that are used to confront the imagery situation of eating that is controlled in an abnormal way up the point that becomes a disease. The four areas with significant difference in patients with anorexia can be integrated in two regions; the first one includes the anterior cingulated and left front medial region, which is related to complex cognitive functions (Ramnani \& Owen, 2004), and their interaction with the corporal feelings control (Tops \& Boksem, 2011); the second one is integrated by the left and right mid brain, which are probably associated to the positive reinforcement experimented by the patients, (Keating et al., 2012). The high control areas are involved since one of the determinant characteristic of these patients are the control of behavior, specially the alimentary one, and other obsessive traits. (Kaye, 1997).

These results differ from classic studies of exposure to stimulus related to appetency in a group of patient with alimentary behavior disorders (Brooks et al., 2011). It is important to take into account that these differences are not just about instruction, but principally about fasting state, thus patients had a medical record of just only restrictive anorexia and were probably hunger before the study.

In studies that included anorexics and bulimics during the evocation of aversive stimulus with food, the left medial orbit frontal and anterior cingulated cortices were activated (Uher et al., 2004). Somehow, this hypothetic situation does not represent either the consummate eating act or the mere exposure to a phenomenon as food, which represents aversion (Ellison et al., 1998) compulsion (Saxena, Brody, Schwartz, \& Baxter, 1998) and like. 
That is why this situation represent part of the mental conflict (Keating, 2010), and for the same reason, the experience of the patient is subjective when facing the successfully controlled act of eating, (Surgenor, Horn, Plumridge, \& Hudson, 2002) where the natural like for the food has been modified (Hall, Arnold, \& Myers, 2000; Nunn, Frampton, Gordon, \& Lask, 2008).

The role of the hedonic state in anorexia has been cited in a positive (Keating et al., 2012) and negative way (Holsen et al., 2012; Jiang, Soussignan, Rigaud, \& Schaal, 2010), and it still being unclear. This phenomenon is similar to the situation in the construct corporal image study (De Preester \& De Preester and Veroniek Knockaert, 2005) of anorexia nervosa (Cash, 2004), where the aversion to the patient's own body (Friederich et al., 2010) and a goal that includes not eating (Fladung et al., 2010) because of an ideal that lacks of objectivity, that means the desire of being skinny, were confirmed. This aspect must be considered in case of appetency, where the like for food could not be lost, but suppress by a goal such as the ideal of thinness.

Possibly, midbrain areas were activated because of the expectant condition of appetency (Davis et al., 2009) because the dopaminergic areas of the ventral tegmental area is involved. This is a possibility that has been proposed on the integration diagram maintenance of anorexia (Fladung et al., 2010). Principally, because it refers to the starvation state of the patient (Gatward, 2001) and its association with the compulsive exercise (Scheurink et al., 2010). It must be as well associated to the reward circuit in a positive way with appetency, that is to say, the eating or not eating act can be conditioned by something else than hunger for a goal, which determines behavior and influences appetency through a top-down mechanism (Kobayashi et al., 2004).

Anorexia nervosa represents an indeterminate perspective (T. F. Hasan \& Hasan, 2011) from not only the biological field, but also from the social aspect because it is needed the integration of the social, physiological, cognitive an phenomenological concepts (Jordi \& Ian, 2001).

The findings do not allow us to elaborate speculations about the mechanism through which the patients affected with Anorexia Nervosa mention not having appetite and are able to maintain their restriction. However, having findings that include cerebral areas involved with higher behavioral goals, and other related with reward, involved with food appetency and hungry, is possible understand the role of self-control and the pleasure in the maintenance the state of starvation in the Anorexia Nervosa. Is possibly that the absence of appetite is not the full reason to motivates the restriction of food in anorexia nervosa (DeBoer, 2011).

The most important limitations of the study are the small size of the sample and the lack of comparative groups that include a higher disorder spectrum of the alimentary behavior, specially explaining the appetency phenomenon in a positive way such as the bulimic nervosa and binge disorder.

The study does not received any kind of external financing to the institution.

\section{REFERENCES.}

Allison, S.\& Timmerman, G. M. (2007). Anatomy of a binge: food environment and characteristics of nonpurge binge episodes. Eating Behaviors, 8(1), 31-38. doi:10.1016/j.eatbeh.2005.01.004

American Psychiatric Association. (2000). Diagnostic and Statistical Manual of Mental Disorders, Fourth Edition. American Psychiatric Association.

Barbano, M. F.\& Cador, M. (2005). Differential Regulation of the Consummatory, Motivational and Anticipatory Aspects of Feeding Behavior by Dopaminergic and Opioidergic Drugs. Neuropsychopharmacology, 31(7), 1371-1381. doi:10.1038/sj.npp.1300908

Beckmann, C. F., Jenkinson, M.\& Smith, S. M. (2003). General multilevel linear modeling for group analysis in FMRI. Neurolmage, 20(2), 1052-1063. doi:10.1016/S1053-8119(03)00435$X$

Berthoud, H.-R. (2006). Homeostatic and nonhomeostatic pathways involved in the control of food intake and energy balance. Obesity (Silver Spring, Md.), 14 Suppl 5, 197S-200S. doi:10.1038/oby.2006.308

Brooks, S. J., O'Daly, O. G., Uher, R., Friederich, H.C., Giampietro, V., Brammer, M., et al. (2011). Differential neural responses to food images in women with bulimia versus anorexia nervosa. (S. J. Brooks, O. G. O Daly, R. Uher, H.-C. Friederich, V. Giampietro, M. Brammer, et al., Eds.)PLoS ONE, 6(7), e22259. doi:10.1371/journal.pone.0022259.t002

Brooks, S. J., O'Daly, O., Uher, R., Friederich, H.-C., Giampietro, V., Brammer, M., et al. (2012). Thinking about Eating Food Activates Visual Cortex with Reduced Bilateral Cerebellar 
Activation in Females with Anorexia Nervosa: An fMRI Study. (M. Tsakiris, Ed.)PLoS ONE, 7(3), e34000. doi:10.1371/journal.pone.0034000.t003

Cash, T. F. (2004). Body image: past, present, and future. Body Image,1(1), 1-5. doi:10.1016/S1740-1445(03)00011-1

Ceaser, M. (1979). Hunger in primary anorexia nervosa. The American Journal of Psychiatry, 136(7), 979-980.

Davis, C. A., Levitan, R. D., Reid, C., Carter, J. C., Kaplan, A. S., Patte, K. A., et al. (2009). Dopamine for "Wanting " and Opioids for 'Liking': A Comparison of Obese Adults With and Without Binge Eating. Obesity, 17(6), 1220-1225. doi:10.1038/oby.2009.52

De Preester, H.\& De Preester and Veroniek Knockaert, E. B. H. (2005). Body Image and Body Schema. John Benjamins Publishing Company.

De Silva, A., Salem, V., Matthews, P. M.\& Dhillo, W. S. (2012). The Use of Functional MRI to Study Appetite Control in the CNS. Experimental Diabetes Research, 2012(4-5), 1-13. doi:10.1097/SLA.0b013e318203a289

De'Angeli, A. G.\& De'Angeli, J. (1993). El gran libro de la cocina mexicana.

DeBoer, M. D. (2011). What can anorexia nervosa teach us about appetite regulation? Nutrition, 27(4), 405-406. doi:10.1016/j.nut.2011.02.001

Ellison, Z., Foong, J., Howard, R., Bullmore, E., Williams, S.\& Treasure, J. (1998). Functional anatomy of calorie fear in anorexia nervosa. The Lancet, 352(9135), 1192. doi:10.1016/S01406736(05)60529-6

Fernstrom, J. D.\& Choi, S. (2008). The development of tolerance to drugs that suppress food intake. Pharmacology \& Therapeutics, 117(1), 105-122. doi:10.1016/j.pharmthera.2007.09.001

Fladung, A.-K., Grön, G., Grammer, K., Herrnberger, B., Schilly, E., Grasteit, S., et al. (2010). A neural signature of anorexia nervosa in the ventral striatal reward system. The American Journal of Psychiatry, 167(2), 206-212. doi:10.1176/appi.ajp.2009.09010071

Friederich, H.-C., Brooks, S., Uher, R., Campbell, I. C., Giampietro, V., Brammer, M., et al. (2010). Neural correlates of body dissatisfaction in anorexia nervosa. Neuropsychologia, 48(10), 2878-2885.

doi:10.1016/j.neuropsychologia.2010.04.036

Gatward, N. (2001). The ability to tolerate starvation: a role in anorexia nervosa? European Eating Disorders Review, 9(6), 359-364. doi:10.1002/erv.448

Gendall, K. A., Sullivan, P. F., Joyce, P. R.\& Bulik, C. M. (1997). Food cravings in women with a history of anorexia nervosa. International Journal of Eating Disorders, 22(4), 403-409.

Hall, W. G., Arnold, H. M.\& Myers, K. P. (2000). The acquisition of an appetite. Psychological Science, 11(2), 101-105.

Hasan, T. F.\& Hasan, H. (2011). Anorexia nervosa: a unified neurological perspective. International Journal of Medical Sciences, 8(8), 679-703.

Hetherington, M. M.\& Rolls, B. J. (1991). Eating behavior in eating disorders: response to preloads. Physiology \& Behavior, 50(1), 101108.

Holsen, L., Lawson, E., Blum, J., Ko, E., Makris, N., Fazeli, P., et al. (2012). Food motivation circuitry hypoactivation related to hedonic and nonhedonic aspects of hunger and satiety in women with active anorexia nervosa and weightrestored women with anorexia nervosa. Journal of Psychiatry \& Neuroscience, 37(5), 322-332. doi:10.1503/jpn.110156

Jiang, T., Soussignan, R., Rigaud, D.,\& Schaal, B. (2010). Pleasure for visual and olfactory stimuli evoking energy-dense foods is decreased in anorexia nervosa. Psychiatry Research, 180(1), 42-47. doi:10.1016/j.psychres.2010.04.041

Jordi, S.\& Ian, B. (2001). embodiment and livid experince in anorexia. Athenea Digital, 1-15.

Kaye, W. H. (1997). Anorexia nervosa, obsessional behavior, and serotonin. Psychopharmacology Bulletin, 33(3), 335-344.

Kaye, W. H., Fudge, J. L. \& Paulus, M. (2009). New insights into symptoms and neurocircuit function of anorexia nervosa. Nature Reviews Neuroscience, 10(8), 573-584. doi:10.1038/nrn2682

Keating, C. (2010). Theoretical perspective on anorexia nervosa: The conflict of reward. Neuroscience \& Biobehavioral Reviews, 34(1), 73-79. doi:10.1016/j.neubiorev.2009.07.004

Keating, C., Tilbrook, A. J., Rossell, S. L., Enticott, P. G.\& Fitzgerald, P. B. (2012). Reward processing in anorexia nervosa. Neuropsychologia, 50(5), 567-575.

doi:10.1016/j.neuropsychologia.2012.01.036

Kirkham, T. C. (2009). Cannabinoids and appetite: Food craving and food pleasure. International Review of Psychiatry, 21(2), 163-171. doi:10.1080/09540260902782810

Kishi, T., \&Elmquist, J. K. (2005).Body weight is regulated by the brain: a link between feeding and emotion. Molecular Psychiatry, 10(2), 132146. doi:10.1038/sj.mp.4001638

Kobayashi, M., Takeda, M., Hattori, N., Fukunaga, M., Sasabe, T., Inoue, N., et al. (2004). Functional imaging of gustatory perception and imagery: "top-down" processing of gustatory signals. Neurolmage, 23(4), 1271-1282. doi:10.1016/j.neuroimage.2004.08.002 
Marrazzi, M. A.\& Luby, E. D. (1986). An autoaddiction opioid model of chronic anorexia nervosa - Marrazzi - 2006 - International Journal of Eating Disorders - Wiley Online Library. International Journal of Eating ....

Morrison, C. D.\& Berthoud, H.-R. (2007). Neurobiology of nutrition and obesity. Nutrition Reviews, 65(12 Pt 1), 517-534. doi:10.1301/nr.2007.dec.517-534

Northoff, G. (2012). From emotions to consciousness - a neuro-phenomenal and neuro-relational approach, $1-17$. doi:10.3389/fpsyg.2012.00303/abstract

Nunn, K., Frampton, I., Gordon, I.\& Lask, B. (2008). The fault is not in her parents but in her insula-A neurobiological hypothesis of anorexia nervosa. European Eating Disorders Review, 16(5), 355360. doi:10.1002/erv.890

Ogawa, S., Lee, T. M., Nayak, A. S.\& Glynn, P. (1990). Oxygenation-sensitive contrast in magnetic resonance image of rodent brain at high magnetic fields. Magnetic Resonance in Medicine : Official Journal of the Society of Magnetic Resonance in Medicine / Society of Magnetic Resonance in Medicine, 14(1), 68-78.

Pylyshyn, Z. (2003). Return of the mental image: are there really pictures in the brain? Trends in Cognitive Sciences, 7(3), 113-118. doi:10.1016/S1364-6613(03)00003-2

Ramnani, N.\& Owen, A. M. (2004). Anterior prefrontal cortex: insights into function from anatomy and neuroimaging. Nature Reviews Neuroscience, $\quad$ 5(3), 184-194. doi:10.1038/nrn1343

Santel, S., Baving, L., Krauel, K., Münte, T. F.\& Rotte, M. (2006). Hunger and satiety in anorexia nervosa: fMRI during cognitive processing of food pictures. Brain Research, 1114(1), 138148. doi:10.1016/j.brainres.2006.07.045

Saxena, S., Brody, A. L., Schwartz, J. M.\& Baxter, L. R. (1998). Neuroimaging and frontal-subcortical circuitry in obsessive-compulsive disorder. The British Journal of Psychiatry. Supplement, (35), 26-37.

Scheurink, A. J. W., Boersma, G. J., Nergårdh, R., \& Södersten, P. (2010). Neurobiology of hyperactivity and reward: agreeable restlessness in anorexia nervosa. Physiology \& Behavior, 100(5), 490-495. doi:10.1016/j.physbeh.2010.03.016

Smith, S. M., Jenkinson, M., Woolrich, M. W., Beckmann, C. F., Behrens, T. E. J., JohansenBerg, H., et al. (2004). Advances in functional and structural MR image analysis and implementation as FSL. Neurolmage, 23 Suppl 1 , doi:10.1016/j.neuroimage.2004.07.051
Surgenor, L. J., Horn, J., Plumridge, E. W.\& Hudson, S. M. (2002). Anorexia nervosa and psychological control: a reexamination of selected theoretical accounts. European Eating Disorders Review, 10(2), 85-101. doi:10.1002/erv.457

Tops, M.\& Boksem, M. A. S. (2011). A potential role of the inferior frontal gyrus and anterior insula in cognitive control, brain rhythms, and eventrelated potentials. Frontiers in Psychology, 2, 330. doi:10.3389/fpsyg.2011.00330

Uher, R., Murphy, T., Brammer, M. J., Dalgleish, T., Phillips, M. L., Ng, V. W., et al. (2004). Medial prefrontal cortex activity associated with symptom provocation in eating disorders. The American Journal of Psychiatry, 161(7), 12381246.

Vallor, S. (2008). The fantasy of third-person science: Phenomenology, ontology and evidence. Phenomenology and the Cognitive Sciences, 8(1), 1-15. doi:10.1007/s11097-0089092-4

Wagner, A., Aizenstein, H., Mazurkewicz, L., Fudge, J., Frank, G. K., Putnam, K., et al. (2008). Altered insula response to taste stimuli in individuals recovered from restricting-type anorexia nervosa. Neuropsychopharmacology, 33(3), 513-523. doi:10.1038/sj.npp.1301443

Willems, R. M., Toni, I., Hagoort, P., \& Casasanto, D. (2010). Neural dissociations between action verb understanding and motor imagery. Journal of Cognitive Neuroscience, 22(10), 2387-2400. doi:10.1162/jocn.2009.21386

Woolrich, M. W., Jbabdi, S., Patenaude, B., Chappell, M., Makni, S., Behrens, T., et al. (2009). Bayesian analysis of neuroimaging data in FSL. Neurolmage, 45(1 Suppl), S173-86. doi:10.1016/j.neuroimage.2008.10.055 